\title{
Non-finite Verb Phrases in Student Translations
}

\author{
Renata Šimůnková \\ Technical University of Liberec, Faculty of Science, Humanities and Education, \\ Department of English Language, \\ Sokolská 8, 46001 Liberec 1, Czech Republic \\ e-mail: renata.simunkova@tul.cz
}

\begin{abstract}
One of the sources of mistakes in English to Czech translations has its roots in the different degree of condensation which is closely related to the use of non-finite verb phrases. The problem is further intensified by differences in the means used to comply with the functional sentence perspective. Teachers of foreign languages, although not primarily trained in translation, are often required to translate by their students or school authorities. This paper focuses on the most common mistakes teacher trainees make when translating non-finite phrases referring to the present or future and mainly to the past. By means of goal directed test translations, mistakes made by students are collected, analysed, and possible correct translations are suggested and discussed. Such analyses used in the classroom facilitate students' awareness of the key structural differences and leads to significant improvement in their translation performance.
\end{abstract}

\section{Introduction}

One of the significant features of English is its tendency towards predications expressed nominally. It is a phenomenon which has been observed and extensively studied by many linguists (e.g. by G. O. Curme in the grammar published already in 1931). Among Czech linguists it is an issue elaborated on by mainly V. Mathesius and later by Vachek, Dušková and others. As Vachek states in his article, "Mathesius more than once pointed out the important part played in good Czech style by a finite verb and stressed the fact that this style is notoriously averse to complicated nominal constructions, fairly common in the good style of English" [1, pp. 63]. As this issue represents a significant structural difference, it is likely to cause problems in translations between the two languages. The problem is further intensified by the differences in the means used to comply with the functional sentence perspective. While the actual linear arrangement of a clause is relative and depends on a particular language, the interpretative arrangement is absolute, and changes in the thematic structure can either change the meaning of a clause or hinder its interpretation.

The natural interest in differences and the curiosity to see how the present awareness of the issue is reflected in the context of future teachers of English education, resulted in a research project supported by the Internal Grant of TUL. Although the teacher training programme is not primarily focused on translation, it should provide students with at least some insights into the problems of translation as it is often assumed that a person who has a diploma in a foreign language is automatically also a translator. It is by no means true as translation requires skills which go far beyond just mere competence or fluency in two languages. However, in their future careers teachers of foreign language will almost certainly be asked to do it. For this reason a compulsory elective course is offered and it was used to gather data for the study concerned. 
The study pursued two aims. The first one was to investigate what difficulties (if any) students have when translating non-finite verb phrases. It is assumed based on the arguments above that students will make mistakes when translating the studied structures. It is however important to find out which non-finite verb phrases are the most difficult for students to deal with. Once this is established it is possible to search for the sources of these mistakes, which was the second aim of the research project. Only then can we raise students' awareness of the problems which can later help to prevent mistakes. This study by no means attempted a quality analysis of translations performed by the students which would have had to be much more complex.

For the aims to be attainable, it was first necessary to establish what the subject-matter of the study actually is, it means what non-finite verb phrases are and how they can be classified. Non-finite verb phrases are those which do not function syntactically as verbs, but usually have nominal character because, as it has been mentioned above, they represent a means of condensation (nominalisation), so typical for English. Their non-finite character resides in the fact that they are not in grammatical concord with a subject and they are not marked for tense. With regards to the actual classification of non-finite verb phrases, a lot of grammar reference books do not deal with the issue at all, or it is mentioned, but not in a systematic way, often at different parts of a book. For our purpose, the classification by Leech and Svartvik [2] will be used and it will be adapted and extended based on the works by Quirk et al. [3] and Dušková [4]. Leech and Svartvik [2, pp. 413] classify non-finite verb phrases into "the infinitive, -ing participle and -ed participle" without any further elaboration on this topic, though. The same set of non-finite phrases is also implied by Quirk et al. [3, pp. 237-239], who further discussed important qualities of non-finite verb phrases which include the fact that they can appear in an active and passive form and with the exception of the -ed participle they can express formal contrast of perfective/nonperfective and progressive/nonprogressive aspect. This extended classification is then also used by Dušková [4, pp. 268-271], who further distinguishes two kinds of -ing form, namely "the gerund", which always functions as a noun, and the present participle and she refers to the -ed participle as "past participle". In our study we will therefore distinguish the following non-finite verb forms: the infinitive, gerund, present participle and past participle and their respective forms: passive, progressive or perfect.

\section{Methods and procedures applied}

As determined by the aims above, the study had to be executed in several steps or stages. First, it was necessary to determine the areas of difficulties, and then these needed to be classified for the purpose of analysis. Based on the results of the analyses, sources of the mistakes could be determined and correct translations together with remedial activities could be suggested.

\subsection{Determining the areas of difficulties}

The first step had already been performed in the choice of the topic - the focus on non-finite verb phrases. This choice was based on the already discussed noticeably difference between the two languages and the fact that, apart from infinitive, non-finite verb phrases are not actively used in present day Czech. It has also been assumed that students are likely to have problems in other areas as well. The selection of these areas was based on information from professional sources [5, 6, 7 and 8] and on our extensive teaching experience. It can be briefly stated that these are mainly issues caused by the different nature of the two languages (Czech being a synthetic language while English analytic) which is then further reflected in the 
different choice of means to comply with the rules of FSP (Functional Sentence Perspective). Specifically they include mistakes in word order, choice of voice (active or passive), the use of articles and existential constructions.

\subsubsection{Preparation of the test translation}

The crucial task of this stage was the selection of the text for translation. First, it needed to include non-finite verb phrases in a suitable quantity. On the other hand it was important for the text not to burden the students with any other specific demands. For this purpose we used the Nord's model of text analysis in translation. Nord [9] introduces two kinds of factors used in the analysis of a text for translation: external which include sender, intention, recipient, medium, time, motive and text function, and internal: subject matter, content, presupposition, non-verbal elements, lexis, sentence structure and suprasegmental features. The aim was to select such a text which would be demanding in only one (sentence structure) factor and neutral in the rest, so the students could really focus on the structures in question and were not distracted by unnecessary difficulties in other areas.

Based on the criteria listed above, a set of texts from BBC news which included the below mentioned non-finite structures and a number of other structures which typically cause problems (existential structures, raised subject, etc.) was selected. The set included 3 articles published on BBC News in November 2014 and altogether it represented 7 standard pages. Students we however not required to translate everything - the sentences containing the grammatical features concerned were highlighted and were translated. The rest of the text provided context and continuity. The students were therefore asked to translate approximately 3 standard pages of text.

\subsubsection{Administration of the test translation}

Students taking part in this study were attendees of a compulsory-elective course called "Translation Seminar". As the text for translation was rather long (even with the reduction mentioned above), students prepared it at home on voluntary basis and sent the translation via e-mail. It was analysed, assessed and then discussed in detail in class. The discussion in the class included the search for and discussion of the potential causes of the problems experienced and a joint effort in the preparation of a correct translation version. 23 students participated in the study.

\section{The analysis of the test translation}

As it has already been mentioned, non-finite verb phrases were classified based on their form and not their function which they played in a sentence in each particular case. Their function was however discussed when the translations were analysed and the reasons for the mistakes were searched for. Due to limited space, it was not possible to include all students' translations for all the structures concerned. Only the samples with the highest information value were selected which are presented in the following form: first, the source sentence is presented in bold writing, then the samples of student translations follow with the translation of the non-finite verb phrase highlighted, and the whole item finishes with a suggested correct translation prepared in a "feedback and discussion" lesson together with the students, presented in bolt letters and in brackets.

\subsection{Infinitive}

In the text there were 11 present forms of infinitive -6 in adverbial function (infinitives of purpose) +5 in nominal function (object) and 5 perfect forms - nominal function. No passive or progressive forms were included. In general, infinitive forms caused the smallest number of 
problems - the only issue was a wrong choice of time reference (the use of the present instead of the past tense in Czech).

\subsection{Gerund}

In the text, there were 7 present forms of the gerund, two in the passive voice and three in perfect forms. All the gerund forms were functioning as objects.

Students seemed to have little difficulty when the non-finite nominal clause in the function of an object was not introduced by a preposition (He claimed having seen him before.). It also seemed quite straightforward if there was a preposition, but the preposition clearly expressed the relation (mainly time relation). Problems, however, occurred in the structures where the preposition expressed a range of possible relations. The situation got even more complicated for the students if a noun with the meaning expressed by a gerund form did not exist in Czech.

The authorities have accused the group of recruiting more than 30 people to fight in Syria in the last year.

- Minulý rok úr̆ady obvinily skupinu z naverbování více než 30 lidí pro boje $v$ Sýrii.

- Státni orgány obvinili skupinu z nabrání vice než třiceti lidí za účelem boje během posledního roku.

- Vláda obvinila skupinu z rekrutování více než 30 lidí pro boj v Sýrii za poslední rok.

- Autority obvinily skupinu Sharia4Belgium za výcvik více než 30 lidí za poslední rok na válku v Sýrii

- Úřady obvinily skupinu, která naverbovala více než 30 lidí k boji v Sýrii během minulého roku.

- Úřady obžalovaly skupinu, která zrekrutovala více jak 30 lidí, kteři bojovali v Sýrii minulý rok.

(Úřady skupinu viní z toho, že za poslední rok naverbovala pro boj v Sýrii více než 30 lidí.)

As can be seen from the examples, approximately half of the students applied literal translation with a deverbal noun which is unnatural in Czech. The second half then chose the correct option with a subordinate clause. In no translation, however, the number of people appeared at the end of the sentence. None of the translations therefore complied with FSP.

\section{I think he's in a state of being a soldier.}

- Myslím, že se stane vojákem. Myslím, že se prostě považuje za vojáka. Myslím, že je ve stádiu vojáka. Myslím si, že se stal vojákem na plný úvazek. Myslím, že se nachází ve vojenském módu. Myslím, že už se z něj stal voják. Myslím, že je ve stádiu vojáka. Myslím, že je ve stádiu, kdy potřbuje být vojákem. Myslím si, že se brzy stane vojákem. Myslím, že se z něj stává voják. Myslím, že se chystá stát se vojákem.

\section{(Myslím, že ted' je prostě voják.)}

The example above is the example of a case where the relation of the gerund form to the rest of the sentence is not clearly expressed. The confusion of students can be seen in the wide choice of tenses ranging from the past tense to the future tense and in both aspects. 


\subsection{Participle forms}

There were 12 present participle forms in the text, all were active, and 11 past participle forms. When functioning as adjectives in an attributive position (information about the growing number of Europeans fighting in Syria), they did not represent any problems. They however caused problems when they were used in real "participle" (clause condensing) function. It was again less difficult (like in the case of the gerund) when the relation between clauses was clear (mainly adverbial of time, condition). Students found the structure most difficult when no relation of subordination or coordination was explicitly expressed.

Taking a yellow sheet of paper from the drawer of her desk she read out loud

- Když vytáhla žlutý papír ze šuplíku, začala č́st

- Poté co vytáhla ze šupliku zažloutlý papir, nahlas četla

- Vytáhnuvši žlutý papír ze šuplíku, nahlas četla ...

(Ze šuplíku vytáhla žlutý papír a začala číst...)

When participles are used as clause condensers they often function as adverbials and for the students this connection might be so tight that none of them realizes that in this situation the relation of coordination is most suitable for the given context. The fact that the use of nonfinite clauses in insubordinate rather than coordinate relation to the rest of the sentence seems to be much more frequent is supported also by Carter and McCarthy [10, pp. 546] who claim that "Non-finite clauses can normally only be subordinate, and typically combine with finite ones in sentences". Quirk [3] and Dušková [4], however, describe their use in the relation of coordination, too. This relation should therefore be something students at the advance level of English should focus on as it might be new for them.

A similar problem is illustrated by the following example. Most of the students tried to retain as much of the source structure as possible and they helped themselves in doing so either by means of explicitly expressing a relation which was not actually there (skupinu povstalcu, jak se pripravuji $k$ boji), or by means of literal translation with the use of participles which nowadays is too old fashioned and therefore unnatural (narovnani $v \check{r}$ adách, sjednoceni do $\check{r} a d . . .$.$) . A special discussion could then be devoted to the translation of the word shakily$ which would however be beyond the scope of the present paper.

A camera shakily films a group of rebel fighters preparing to pray, lined up in rows, their weapons at their feet.

- Kamera roztřeseně filmuje skupinu povstalcủ, kteři se právě chystají $k$ modlitbě, seřazení v řadách a jejich zbraně jim leži u nohou.

- Roztřesený kameraman natáči skupinu povstalcủ, kteři se připravuji na modlitbu, narovnaní v řadách, se složenými zbraněmi.

- Třesoucí se kamera natáči skupinu povstalců, jak se připravuji k modlení sjednoceni do r̆ad se zbraněmi u nohou.

- Roztřesená kamera zachytává záběry rebelské skupiny bojovniků, kteři se připravuji k modlitbě. Jsou seřazeni v řadách, zbraně maji odložené u nohou.

- Kamera natáči třesoucí záběry skupiny vojákỉ, rebelů se zbraněmi, kteři jsou srovnané v jedné řadě a připravené $k$ modlitbě.

- Rozechvělá kamera natáčela skupinu povstalcủ, která se chystala modlit. Vyrovnani v radě jim zbraně ležely u nohou. 
(Kamera neobratně zachycuje skupinu rebeli̊. Jsou vyrovnaní v řadách, zbraně u nohou.)

In the text, there were 8 cases of the perfect participle, 6 were in the active voice and 2 in the passive. Students seem to have understood the main function of the perfect form of the perfect participle, the reference to the past, correctly. When they chose a clause as a means of translation, time reference was usually not a problem. The mistakes made in this sentence were usually caused by them not using a clause, but a participle form or a deverbal noun. When they used a clause, some of them used the passive, for which in this context there was no reason and it therefore had to be considered an inappropriate translation.

Having received information about the growing number of Europeans fighters in Syria, intelligence agencies Gross Europe have stepped up investigations.

- Po dozvědění se informací ohledně vzrůstajicího počtu evropských bojovníků $v$ Sýrii, zpravodajské služby odstartovali řadu vyšetrování např́č Evropou.

- Po obdržení informaci týkajících se rostoucího počtu Evropanu bojujících $v$ Sýrii, zahájily zpravodajské agentury napríč Evropou vyšetřování.

- Poté, co byla obdržena informace o vzrůstajícím počtu evropských bojovníků v Sýrii, inteligenční agentury po celé Evropě se zapojily do vyšetřování.

- Zpravodajské služby celé Evropy začaly s vyšetřováním, na základě obdržených informací o vzrůstajícím počtu Evropanů bojujících v Sýrii.

Evropské tajné služby, na základě informací o vrůstajícím počtu Evropanů, kteří se zapojují do bojů v Sýrii, zintenzivnily pátrání.

\subsection{Other problems}

Although the study was primarily focused on the translation of non-finite verb phrases, the other mistakes in structure established above were also studied. The biggest problem in this area seemed to be the failure to comply with the FSP. Students tended to copy the word order and the sequence of clauses not realizing that doing so, they were violating the natural pattern of communication dynamism going from known information to new.

The authorities have accused the group of recruiting more than 30 people to fight in Syria in the last year.

(Úřady skupinu viní z toho, že za poslední rok naverbovala pro boj v Sýrii více než 30 lidí.)

This sentence has already been discussed in connection with the gerund form used (examples of student translations are listed above). It needs to be repeated here that none of the students translated it with the number of at the end. The FSP of the sentence was thus violated since the facts that fights are in Syria and that they were there last year too is known information. What is new and should be surprising is the number of people recruited by just one particular group.

A young man walks into shot and takes off his rifle before briefly turning towards the camera.

- Mladý muž, který se objevuje v závěru, si sundává kalhoty, dřive, než se otoči primo do kamery.

- Jeden mladík vchází do záběru a pokládá svou pušku před krátkým pohledem do kamery. 


\section{Do záběru vchází mladik, z ramene si sundá pušku a letmo se otočí na kameru.}

The sentence above represents a typical example of the failure to comply with FSP in translation. As the subject of the first clause is used with specific indefinite reference (manifested by an indefinite article), it clearly is new information and it therefore needs to be at the end of the clause if possible, which can easily be performed in Czech. This sentence is also another example of the problem caused by participles discussed above where the students wrongly feel that in their translation they have to employ an explicitly expressed relation of subordination (dř́ve, než se otočí; pred krátkým pohledem..). One student came up with an amusing translation of the word rifle (the first sample).

The UK has increased efforts to track how fighters are recruited and funded.

- Spojené království zvýšilo snahu o zjištění, jak jsou budoucí bojovníci nalézáni a rekrutováni.

(Velká Británie začala intenzivněji pátrat po tom, jak bojovníky verbují a financují).

All the students used the passive. It is not really wrong in Czech, but unnatural - no need to use the passive since in Czech a subject (in this case also the agent) can be left out even in the active structure and not doing so represents a failure to use the means available in Czech efficiently. The FSP stays the same regardless the voice used. Another example of a wrong translation by means of the passive voice is presented in the example below.

\section{Questions have also been asked about what Muslim leaders are doing to deal with the problem.}

- Bylo vzneseno několik otázek o tom, co dělají muslimští vůdci pro to, aby se problém vyřešil.

- Byly kladeny také dalši otázky, jestli muslimští vưdci chtěji tento problém řešit.

- Také byly kladeny otázky o tom, co dělaji muslimští lídři pro vyrovnání se s problémem.

(Otázkou (ovšem také) je/ objevily se otázky ....)

The last problem which will be discussed in this article is a structure with a raising-to-subject verb and a non-finite subordinate clause in the form of infinitive. Although the infinitive as such has been already discussed at the beginning of the article, it has been decided to deal with this particular structure separately as it represents a specific and distinct example of the use of the infinitive. Raising in general refers to a phenomenon where a particular verb phrase has a dependent that semantically does not belong to it, but is rather semantically connected with an embedded verb phrase. In Czech raising is not applied and therefore students were not able to use word for word translation, and moreover had to be acquainted with this issue to be able to approach it efficiently, which was the case for only a few of them. The first two examples illustrate that the students did not understand the meaning or changed the meaning in their translation without being aware of it. The second two examples illustrate the choice of a wrong structure which nevertheless at least expresses the meaning intended.

UK, France, Denmark, Belgium and other EU nations are assumed to have significant numbers involved in the fighting.

- Velká Británie, Irsko, Francie, Dánsko, Nizozemsko a dalši národy Evropské unie se domnívají, že zaujímají podstatnou roli $v$ boji.

- Velká Británie, Irsko, Francie, Dánsko, Nizozemsko a dalši státy Evropské Unie jsou přesvědčeny, že zastávají významnou roli v boji. 
- Domnívá se, že (vynechány místa pro názvy států, ale názvy nepřeloženy) Holandsko a dalši evropské státy mají také velké zastoupení v bojich

- Je předpokládáno, že Spojené království...maji v bojích zapojeno značné množství lidí.

(Bojů se pravděpodobně účastní velké množství bojovníků ze Spojeného království ....)

\section{Conclusion}

The aim of this article is to offer an insight into the translation competence of in-service teacher trainees at the Department of English of FP TUL in the area of non-finite verb phrases. The choice of the focus of the study has been inspired by the contrast between English and Czech represented by the predominantly nominal character of English reflected in a significantly higher degree of condensation and a complex system of non-finite verb phrases as opposed to verbal character of Czech. Students' competence was tested by means of a carefully designed test translation.

The assumption that non-finite verb phrases cause problems in translation from English to Czech has been confirmed, but not to the extent expected. The students almost did not have problems with time reference of perfect forms of non-finite verb phrases and did not seem to have big difficulties when the phrases were used in nominal or adjectival functions, as long as a suitable noun or adjective existed in Czech. They also reasonably efficiently dealt with participle forms used as clause condensers where the relation to the rest of the sentence was clearly subordinate and adverbial or where the condensed structure functioned as a relative clause. The students however ran into significant difficulties where a non-finite phrase in the function of a condenser needed to be translated by means of coordination or when the relation to the rest of the sentence was not explicit or clear. In general, however, the source of the biggest difficulties lay elsewhere than in non-finite structures. The main issue was the failure to comply with the FSP caused by the insufficient awareness of the function of articles and the use and function of the passive. Another problem students were not able to deal with was represented by structures with a raising-to-subject verb.

The insights into areas which students find difficult are always really valuable as they help teachers to focus on these areas and work on them together with the students. These joint analyses and searches for suitable solutions are invaluable sources of progress and improvement.

\section{Acknowledgements}

This research has been supported by the Student Grant Competition of FP TUL, SGS 58005 .

\section{Literature}

[1] VACHEK, J.: Some Thoughts on the So-Called Complex Condensation in Modern English. Sborník praci Filozofické fakulty brněnské univerzity. A, Řada jazykovědná. 1955, Volume 4, pp. 63-77.

[2] LEECH, G.; SWARTWIK, J.: A Communicative Grammar of English. Pearson Education Limited, 2002. ISBN 0-582-50633-6.

[3] QUIRK, R.; GREENBAUM, S.; LEECH, G.; SVARTVIK, J.: A Comprehensive Grammar of the English language. Longman, 1985. ISBN 0-582-51734-6. 
[4] DUŠKOVÁ, L.: Mluvnice současné angličtiny na pozadí češtiny. Praha, Academia, 1994. ISBN 80-200-0486-6.

[5] SPARLING, D.: English or Czenglish. Praha, SPN, 1990. ISBN 80-04-25969-3.

[6] ADAM, M.: The Riches of Students' Mistakes Rediscovered (Czech Interference in Learning English). Part 1. Masaryk University Brno: Dept. of English Language and Literature, 2006. 2 s. The Messenger. Vol. 6, No. 1+2. ISSN 1214-6676.

[7] ADAM, M.: The Riches of Students' Mistakes Rediscovered (Czech Interference in Learning English). Part 2. Masaryk University Brno: Dept. of English Language and Literature, 2007. 2 s. The Messenger. Vol. 7, No.1. ISSN 1214-6676

[8] AUERSPERGOVÁ, M.: Jazyk studentů ekonomie - Czenglish? Acta oeconomica Pragensia. 21(4). 2013, pp. 86-93. ISSN 0572-3043.

[9] NORD, C.: Text Analysis in Translation. Theory, Method, and Didactic Application of a Model for Translation-Oriented Text Analysis. Amsterdam/Atlanta GA, Rodopi, 1991. ISBN 90-5183-311-3.

[10] CARTER, R.; McCARTY, M.: Cambridge Grammar of English. Cambridge University Press, 2006. ISBN 0-521-58846-4.

Mgr. Renata Šimůnková, Ph.D. 


\section{NEURČITÉ SLOVESNÉ TVARY V PŘEKLADECH STUDENTU゚}

Jedním ze zdrojů chyb při překladech $\mathrm{z}$ anglického do českého jazyka je rozdílný stupeň kondenzace, který je těsně spojený s použiváním neurčitých slovesných tvarů. Problém je dále prohlouben rozdílnými prostředky, které zmíněné jazyky používají, aby vyhověly funkční větné perspektivě. Učitelé cizích jazyků, ačkoli $\mathrm{k}$ tomu nejsou primárně připravováni, jsou často nuceni překlady provádět. Článek se zaměřuje na nejčastější chyby, kterých se studenti učitelství angličtiny dopouští při překladech neurčitých slovesných vazeb. Pomocí ř́zeného překladového testu se nejprve provede sběr chyb, dále následuje jejich analýza a vyhodnocení. Výsledky se poté diskutují společně se studenty, hledají se zdroje chyb a možná správná překladová řešení. Využití zmíněné analýzy a diskuse ve výuce zvyšuje povědomí studentů o problémech a řešeních $\mathrm{v}$ dané oblasti a vede $\mathrm{k}$ významnému zlepšení $\mathrm{v}$ dovednostech překladu.

\section{INFINITE VERBFORMEN IN ÜBERSETZUNGEN VON STUDIERENDEN}

Eine der Fehlerquellen bei Übersetzungen aus dem Englischen ins Tschechische ist ein unterschiedlicher Grad der Kondensation, der eng mit Verwendung von infiniten Verbformen verbunden ist. Ein zusätzliches Problem stellen die unterschiedlichen Mittel dar, deren beide Sprachen für die funktionale Satzperspektive verwenden. Die Fremdsprachenlehrer werden oft dazu gezwungen, Übersetzungen durchzuführen, obwohl sie darauf nicht primär vorbereitet werden. Der Artikel konzentriert sich auf die häufigsten Fehler, die den Studierenden für das Lehramt Englisch bei Übersetzungen von infiniten Verbformen unterlaufen. Mithilfe eines gelenkten Übersetzungstests wird zuerst eine Fehlersammlung durchgeführt, darauf folgen Analyse und Auswertung. Die Ergebnisse werden zusammen mit Studenten diskutiert, dabei werden die Fehlerquellen und richtige Übersetzungslösungen gesucht. Im Endeffekt wird das Bewusstsein der Studenten von Problemen bei Übersetzungen erhöht und eine bedeutsame Verbesserung in Übersetzungsfähigkeiten erreicht.

\section{BEZOKOLICZNIKOWE FORMY CZASOWNIKÓW W TŁUMACZENIACH STUDENTÓW}

Jednym ze źródeł błędów popełnianych w thumaczeniach z języka angielskiego na język czeski jest odmienny sposób używania form skróconych, ściśle związany ze stosowaniem bezokolicznikowych form czasowników. Dodatkowy problem stanowią odmienne środki stosowane $\mathrm{z}$ obu językach $\mathrm{w}$ celu zachowania funkcjonalnej perspektywy zdania. Nauczyciele języków obcych są często zmuszani do wykonywania tłumaczeń, choć nie było to głównym przedmiotem procesu ich kształcenia. W niniejszym opracowaniu skupiono się na błędach najczęściej popełnianych przez studentów nauczania języka angielskiego w thumaczeniach bezokolicznikowych form czasownikowych. W pierwszej kolejności w przetłumaczonych tekstach identyfikowane są błędy, które następnie poddaje się analizie i ocenie. W dalszej kolejności wyniki są omawiane ze studentami. Szuka się źródeł błędów i możliwych poprawnych wersji thumaczenia. Zastosowanie $\mathrm{w}$ nauczaniu wspomnianej analizy i dyskusji podnosi wiedzę studentów na temat problemów i rozwiązań w danej dziedzinie i prowadzi do znacznej poprawy umiejętności tłumaczenia. 